\title{
CONTROL AND VIABILITY OF BEE NOSEMOSES
}

\author{
Igor Stojanov ${ }^{1 *}$, Radomir Ratajac ${ }^{1}$, Jasna Prodanov Radulović ${ }^{1}$, \\ Jelena Petrović́ ${ }^{1}$, Mirjana Bojanić Rašović ${ }^{2}$, Ivan Pušić ${ }^{1}$ \\ ${ }^{1}$ Scientific Veterinary Institute "Novi Sad“, Novi Sad, Republic of Serbia \\ ${ }^{2}$ Biotechnical Faculty, University of Montenegro, Podgorica, Montenegro
}

\begin{abstract}
Nosemosis is a bee disease practically present in all countries of the world. The control of the presence of Nosema apis and Nosema ceranae is of great importance. The consequences for bees will depend on the degree of infection of a bee colony. Weakening of bee colonies, reduction of production potentials, contamination with bee feces from hives, death of bees and / or their complete disappearance are some of the signs of the disease. The bee life physiology, which largely depends on the season, and regular control of the pathogen presence can determine the perspective of the disease. The consequences of reduction of the number of bee colonies are not only reflected in a smaller amount of bee products (honey, royal jelly, pollen, wax), but also in agricultural production in the form of reduced pollination. Domestic and international trade in bee products plays an important role in the transmission of Nosema spp. and other infectious and parasitic diseases of bees. Therefore, the control of the presence and viability of Nosema spp. in some bee products is important. Our analysis showed that the control of the presence of the cause of nosemosis in our conditions, without clearly defined legal regulations, is insufficient with regards to the number of beekeepers, bee colonies and hives. On the other hand, reducing the viability of Nosema spp. in different temperature conditions provides an opportunity for safe trade.
\end{abstract}

Key words: bees, nosemosis, control, viability

${ }^{1 \star}$ Corresponding Author: igor@niv.ns.ac.rs 


\title{
KONTROLA I VIABILNOST UZROČNIKA NOZEMOZE PČELA
}

\author{
Igor Stojanov ${ }^{1}$, Radomir Ratajac ${ }^{1}$, Jasna Prodanov Radulović ${ }^{1}$, \\ Jelena Petrović́ ${ }^{1}$, Mirjana Bojanić Rašović ${ }^{2}$, Ivan Pušić ${ }^{1}$ \\ ${ }^{1}$ Naučni institut za veterinarstvo „Novi Sad“, Novi Sad, Republika Srbija \\ ${ }^{2}$ Biotehnički fakultet Univerziteta Crne Gore, Podgorica, Crna Gora
}

\section{Kratak sadržaj}

Nosemoza predstavlja bolest pčela praktično prisutnu u svim zemljama sveta. Kontrola prisustva Nosema apis i Nosema ceranae od velike je važnosti jer u zavisnosti, od pre svega, stepena zaraženosti društva zavisiće i posledice po pčele. Slabljenje pčelinjih zajednica, smanjenje proizvodnih mogućnosti, zaprljanost košnica pčelinjim fecesom, uginuće pčela i/ ili njihovo potpuno nestajanje su neki od znakova oboljenja. Fiziologija života pčela koje najvećim delom zavisi od godišnja doba i redovna kontrola prisustva uzročnika mogu da odrede perspektivu bolesti. Posledice smanjenja broja pčelinjih društava ne ogledaju se samo u manjoj količini pčelinjih proizvoda (med, mleč, polen, vosak) već se njihov nedostatak direktno odražava i na poljoprivrednu proizvodnju smanjenjem oprašivanja. Domaća i međunarodna trgovina proizvodima od pčela igra važnu ulogu u prenošenju Nosema spp. i drugih infektivnih i parazitskih bolesti pčela. Zato je kontrola prisustva i preživljavanja Nosema spp. u nekim pčelinjim proizvodima važna. Naša analiza je pokazala da je kontrola prisustva uzročnika nozemoze u našim uslovima, bez jasno definisane zakonske regulative, mala u odnosu na broj pčelara, pčelinjih društava i košnica. Sa druge strane smanjenje mogućnosti preživljavanja Nosema spp. u različitim temperaturnim uslovima pruža mogućnost za bezbednu trgovinu.

Ključne reči: pčele, nozemoza, kontrola, vijabilnost

\section{INTRODUCTION}

Honeybees (Apis mellifera) are organisms that are very well adapted and able to survive in different climate, geographical and ambient living conditions. For these reasons, bees are capable of successful reproduction and development around the planet. Today, the importance of their presence is meas- 
ured by economic results, directly, by the value and scope of bee products, and indirectly in agriculture by their role in pollination (Aizen and Harder, 2009; Bradbear, 2009). The presence of the causative agent of nosemosis directly leads to a decrease in the lifespan of bees, increased winter death, it affects the strength of bee colonies and their productivity (Botías et al., 2013). The possibility of relocating bee colonies and international trade has contributed, on the one hand, to better economic conditions for beekeepers, and on the other hand, it enabled bee products to reach the markets around the world. The trade of queens and bee products (honey, royal jelly, propolis, wax and bee venom), led to a risk of spreading various infectious and parasitic bee diseases. Any of the mentioned forms of trade in bee products can lead to the transmission of the following: the causative agent of American foulbrood of honey bees (Paenibacillus larvae), European foulbrood (Melissococcus plutonis, Streptococcus pluton, Bacillus alvei, Achromobacter eurydice, Streptococcus faecalis, Bacillus laterosporus), Nosemosis (Nosema apis, Nosema ceranae), Varroa (Varoa destructor), Ethinosis (Aethina tumida), Tropileleosis (Tropilaelaps spp.), Ascospherosis (Ascosphaera apis) and various viral diseases (Mutinelli, 2011).

This study will highlight the problem of nosemosis in beekeeping. Nosemosis is an infectious disease of the digestive tract of bees caused by a single-celled parasite, formerly classified as a protozoan, which today belongs to fungi (Microsporidia) (Adl et al., 2005). Nosema is an intracellular parasite that attacks the epithelial cells of the middle part of the bee's gut. Infection occurs by consuming contaminated food or water, sharing food between bees and during hive cleaning (Martın-Hernandez et al., 2018). The study will look into the data on the number of examined bee samples during the last 6 years (2015 - 2020), with the aim to draw attention to the importance of laboratory analyses. The data related to the sensitivity of the pathogens of nosemosis to different temperatures and the possibility of their viability in different temperature conditions will also be presented.

\section{MATERIAL AND METHODS}

During 6 years, a total of 95 bee samples were examined for the presence of the nosemosis. The samples that were analysed were mostly living bees - few of them were dead bees. The tested materials contained $\geq 50$ bees per sample. If the bee samples were alive, they were placed on ice or in jars with cotton wool soaked in ether in order to anesthetize (MacInnis et al., 2020). After $10 \mathrm{~min}$ utes, the abdominal part of the bee carcass was cut off. A few millilitres of water or saline solution and 20 - 50 severed bees should be placed in the mortar. If 
the total number of spores needs to be determined, it is necessary to add saline solution (or water) in the quantity of 1 millilitre per bee (Fries et al., 2013). The abdomen is macerated with a pestle. The contents of the abdomen, light or dark ochre in colour, which have accumulated at the bottom of the mortar are transferred to a glass slide. The water is added if the contents are too thick. Drops of abdominal contents of bees that are transferred to the slide are covered with a cover glass. Microscopy is performed at a magnification of x 400 .

\section{RESULTS AND DISCUSSION}

Nosemosis is an infectious bee disease that can be caused by two types of nosema: Nosema apis type A nosemosis and Nosema ceranae type C nosemosis (Higes et al., 2010; Martın-Hernandez et al., 2018). In addition to these two species, the presence of Nosema neumanni was confirmed in Uganda (Chemurot et al., 2017), which, according to its characteristics and pathogenesis, in not significantly different from the two above mentioned ones. The differentiation between N. apis and N. ceranae is almost impossible without the application of molecular methods, despite the fact that there are some morphological differences between their spores (Ptaszynska et al., 2014; Pelin et al., 2015). In addition to these characteristics, these two types of nosemosis also differ in clinical picture and pathogenesis. Nosemosis caused by Nosema apis is characterized by the finding bee feces in the hive and at the entrance of a hive, a decrease in the amount of collected honey, weakened movement in and out of the hive, increased death rate during winter and reduced development in spring (Fries, 1993). In nosemosis caused by $N$. ceranae, the mentioned symptoms are mostly absent or weakly expressed, while the general weakness of the bee colony and the increase in mortality are intensified (van der Zee et al., 2014).

Examination of bees for the presence of the cause of nosemosis was connected with the other analysis of the samples, which were brought for the control of the presence of some bacterial or parasitic diseases: American foulbrood of honeybees, varroasis, chalkbrood (Ascosphaera apis) and stonebrood (Aspergillus flavus, Aspergillus nomius and Aspergillus phoenicis). All the tests that were performed, were related to the clinical changes in the bee brood or the bees themselves, where the owners brought samples in relation to beekeeping practice and experience. Table 1 contains the data on testing bees for the presence of the causes of nosemosis in the period 2015 - 2020. 
Table1. The results of bee samples testing for the causes of nosemosis in a period of 6 years

\begin{tabular}{|c|c|c|c|c|c|c|c|c|c|}
\hline & 2015 & 2016 & 2017 & 2018 & 2019 & 2020 & $\Sigma$ & + & - \\
\hline \multicolumn{10}{|l|}{$\begin{array}{l}\text { South Bačka } \\
\text { District }\end{array}$} \\
\hline Novi Sad & 2 & 19 & 8 & 8 & 12 & 1 & 50 & 37 & 13 \\
\hline Beočin & 2 & 2 & & 1 & & & 5 & 4 & 1 \\
\hline Bečej & 6 & & 3 & & & 3 & 12 & 12 & 1 \\
\hline Bačka Palanka & 1 & 2 & 2 & 2 & & & 7 & 6 & 1 \\
\hline $\begin{array}{l}\text { Bački } \\
\text { Petrovac }\end{array}$ & & 4 & 3 & & & & 7 & 4 & 3 \\
\hline Bač & & & 2 & & & & 2 & 1 & 1 \\
\hline Titel & & 3 & & & & & 3 & 0 & 3 \\
\hline Temerin & 1 & & & & & & 1 & 1 & 0 \\
\hline \multicolumn{10}{|l|}{ Srem District } \\
\hline Sr. Karlovci & & & 1 & & & & 1 & 0 & 1 \\
\hline Ruma & & & & & 3 & & 3 & 3 & 0 \\
\hline Indija & & & & 1 & & & 1 & 1 & 1 \\
\hline Sr. Mitrovica & & & & 2 & & & 2 & 2 & 0 \\
\hline
\end{tabular}

\section{Central}

Serbia

\begin{tabular}{cccccccccc}
\hline Kragujevac & & & & 1 & & & 1 & 1 & 0 \\
\hline$\Sigma$ & $\mathbf{1 2}$ & $\mathbf{3 0}$ & $\mathbf{1 9}$ & $\mathbf{1 5}$ & $\mathbf{1 5}$ & $\mathbf{4}$ & $\mathbf{9 5}$ & $\mathbf{7 0}$ & $\mathbf{2 5}$
\end{tabular}

During the examination, the samples from two epizootiological areas were analysed: South Bačka and Srem District. Table 2 shows the data of the Association of Beekeeping Organizations of Serbia (Savez Pčelarskih Organizacija Srbije - SPOS), which were obtained from the Veterinary Directorate of the Ministry of Agriculture in December 2018.

Table 2. Number of beekeepers, beehives and marked hives in Serbia in 2018

\begin{tabular}{lccc}
\hline $\begin{array}{l}\text { Bee holder } \\
\text { district }\end{array}$ & $\begin{array}{c}\text { Number of } \\
\text { beekeepers }\end{array}$ & $\begin{array}{c}\text { Number of } \\
\text { apiaries }\end{array}$ & $\begin{array}{c}\text { Number } \\
\text { of marked } \\
\text { beehives }\end{array}$ \\
\hline South Bačka & 1,203 & 1,233 & 64,694 \\
\hline Srem & 760 & 782 & 45,411 \\
\hline Total in Serbia & 25,830 & 27,158 & $1,295,545$ \\
\hline
\end{tabular}


The examination of bees for the presence of the causes of nosemosis was part of the Annual Monitoring program for Animal Diseases in the Republic of Serbia for determining the program of animal health protection measures (sub law document).

During these 6 years, the program of control and monitoring has not considered bee illness connected with Nosema spp..The program included control and monitoring only of the causative agents of American foulbrood of honeybees, varroasis, tropylelosis and ethinosis.

The examined samples exclusively arrived for laboratory analysis with clinical findings related to large number of deaths in apiaries or disappearances of broods, poor conditions of bee colonies characterized by weakness of broods with reduced number of bees, suspicion of American foulbrood of honeybees. Beside to the findings of nosemosis, other causes of bee diseases were diagnosed: Paenibacillus larvae, Varroa destructor and Ascosphaera apis in one case.

The examinations that were conducted were mostly related to the end of winter and the beginning of spring. This fact indicates that, due to the absence of mandatory control, beekeepers bring samples for analysis at the moment when clinical problems have appeared. It is mainly the weakness of bee colonies, reduced number of bees, the death of bees or their complete disappearance.

The data from the literature (Botías et al., 2013) show how important it is to control the presence of Nosema spp., and the period, i.e., the part of year when the examination is performed. The authors examined the effect of the drug (nozecid) used to control nosemosis during the autumn and the spring, as well as a different number of treatments. Nosema spp. was confirmed in all study groups and the control group, too. Depending on the number of treatments with selected nozecid, the presence of Nosema spp.sp. decreased from $100 \%$ to $20-30 \%$. A special effect was in the period before winter when bee colony is burdened with a very small percentage of the presence of Nosema spp.sp. or not even detected.

The possibility of spreading nosemosis was proven by the presence of Nosema spp. in the large wax moth (Galleria mellonella) (Ozgor et al., 2017). It is known that the large wax moth attacks weak bee colonies exposed to various parasitic or infectious diseases or those that are affected by pesticides from the environment (Ellis et al., 2013). The authors confirmed the presence of $N$. apis and N. ceranae by genotypic and phenotypic methods. The question to consider is - What is the infectious dose necessary for bees to become infected with microsporidia Nosema spp. Previous research has indicated that the average infectious dose for N. apis is 94.3 spores per bee, while for N. ceranae it is slightly higher, 149 spores per bee (Fries, 1988). Recent research indicates that 
1.28 spores per bee are sufficient to cause nosemosis (McGowan et al., 2016). After the spores enter the digestive tract, the nosema transmits theirs sporoplasm to the enterocytes through its filaments, after which they multiply. The passage of spores along the digestive tract can lead to new infections along the intestines or their excretion (Martın-Hernandez et al., 2018). Occurrence of empty spores of Nosema spp. during the analysis of bee samples may indicate autoinfection with nosema, which, then causes intense decay of bee enterocytes (Higes et al., 2007; Higes et al., 2009).

Control of bee nosemosis should include determining the degree of infection of bees within a colony. In this way, it can be determined whether the bees are overloaded with Nosema spp. and whether it poses a threat to bee colony health. This is especially important if the displayed data is analysed. In 6 years, a total of 95 bee samples were examined for the presence of the cause of nosemosis. The samples were taken from two epizootiological areas which together, according to SPOS data from 2018, have just over 100,000 marked hives. On the other hand, it is particularly important to point out that tests are necessary before wintering bees. The presence of Nosema spp., even to a lesser extent in the autumn, can lead to their significant multiplication during the winter, due to autoinfection and the inability to clean the bee colonies due wintering. To determine whether bees are overloaded with nosemosis spores, it is necessary to prepare 25 - 50 bee abdomens. For each bee, it is necessary to add $1 \mathrm{~mL}$ of water before maceration. From the obtained suspension, $10 \mu \mathrm{L}$ should be added to each haemocytometer chamber. The chambers should be examined at magnification of $\mathrm{x} 400$ and the observed spores should be counted. The obtained number of spores should be multiplied by 50,000 and that is the number of spores per bee (Fries et al., 2013).

There are some data showing that the causative agents of nosemosis, $N$. apis and N. ceranae are highly resistant to increased or decreased temperatures and humidity and that these two types of Nosema are not equally resistant to changes in temperature. $N$. ceranae show greater resistance to elevated temperatures while spores lose their ability to survive at $-18{ }^{\circ} \mathrm{C}$ after one week and are significantly more sensitive in this respect compared to $\mathrm{N}$. apis. Those are significantly sensitive, in respect to N. apis (Fenoy et al., 2009; Malone et al., 2001; Martín-Hernández et al., 2009). These characteristics of Nosema may be the reason for a greater presence of $N$. apis in Northern European regions while N. ceranae is more present in the South (Retschnig et al., 2017). The study of viability and infectivity of $N$. ceranae after different temperature treatments of honey and beeswax was analysed in the paper presented by MacInnis et al. (2020). The authors wanted to determine to what extent survival and in- 
fectivity of $N$. ceranae exposed to different temperatures during a period of one week to one year can be reduced. Exposure of honey with $N$. ceranae spores to the temperatures of $33{ }^{\circ} \mathrm{C}, 20^{\circ} \mathrm{C},-12{ }^{\circ} \mathrm{C}$ and $-20^{\circ} \mathrm{C}$ showed that the viability of microsporidia decreased by more than $50 \%$ after 4 weeks at $33^{\circ} \mathrm{C}$, after 100 days at $20^{\circ} \mathrm{C}$ while a slightly decreased viability to $80 \%$ was recorded at $-12{ }^{\circ} \mathrm{C}$, and viability remained unchanged at $-20^{\circ} \mathrm{C}$. When it comes to wax samples, the chance of spore survival fell to less than $10 \%$ after a week of exposure to temperatures of $33{ }^{\circ} \mathrm{C},-12{ }^{\circ} \mathrm{C}$ and $-20{ }^{\circ} \mathrm{C}$, while at $20^{\circ} \mathrm{C}$ viability dropped to $50 \%$ after 42 days.

\section{CONCLUSION}

Bee control for the presence of Nosema spp. is important both for bee health and the yields provided by the bees. The damage caused by the development of diseases and the weakening of colonies by infected bees is directly related to the reduction of bee production. The presence of Nosema spp. is, it might be said, a "silent killer" of beehives, especially if not controlled.

The analysis carried out in this study shows that during 6 years, an average of 17.5 bee samples are examined in one year. Considering the number of registered beehives and marked hives, the number of examined samples is so low that it represents a statistical error. Examination of samples for the presence of Nosema spp. can also be carried out in beekeeping organizations. It may be a good idea to share the data obtained by these controls with similar organizations in different municipalities, especially if these are the areas where hives are moved to during the feed season. It would also be good to inform the institutions dealing with animal health about the conducted analyses.

The knowledge of sensitivity/resistance of Nosema spp. in relation to the temperature differences during the year (the seasons) and geographical characteristics, as well as of their survival potential and maintenance of their infectivity can contribute to reduction of harmful effects of these microorganisms.

\section{ACKNOWLEDGEMENT}

This study was funded by Ministry of Education, Science and Technological Development of The Republic of Serbia by the Contract of implementation and funding of research work of NIV-NS in 2021, Contract No: 451-039/2021-14/200031 and was also supported by Provincial Secretariat for Agriculture, Water Management and Forestry of Vojvodina, Contract No: 104-401$4672 / 2021 / 01$. 


\section{Author's Contribution:}

IS, JP and MBR made contributions to conception and design of the article, they were involved in data collection and drafting the manuscript. IP, JPR, $\mathrm{RR}$ and IS contributed with data about bee colonies, present diseases, microbiological results and estimation of epizootiological status. They revised the manuscript critically and together with IS, JP, MBR and JPR prepared the final draft of the manuscript. All authors read and approved the final manuscript.

\section{Competing interest}

The authors declare that they have no competing interests.

\section{REFERENCES}

1. Adl S.M., Simpson A.G.B., Farmer M.A., Andersen R.A., Anderson O.R., Barta J.R., Bowser S. S., Brugerolle G., Fensome R. A., Fredericq S., James T. Y., Karpov S., Kugrens P., Krug J., Lane C. E., Lewis L. A., Lodge J., Lynn D. H., Mann D. G., McCourt R. M., Mendoza L., Moestrup O., MozleyStandridge S. E., Nerad T. A., Shearer C. A., Smirnov A. V., Spiegel F. W., Taylor M. F. J. R. 2005. The new higher level classification of Eukaryotes with emphasis on the taxonomy of protist. Journal of Eukaryotic Microbiology, 52, 2, 399-451. doi: 10.1111/j.1550-7408.2005.00053.x.

2. Aizen M.A. and Harder L.D. 2009. The global stock of domesticated honey bees is growing slower than agricultural demand for pollination. Current Biology, 19, 11, 915-918. doi: 10.1016/j.cub.2009.03.071.

3. Bradbear N. 2009. Bees and their role in forest livelihoods. A guide to the services provided by bees and the sustainable harvesting, processing and marketing of their products. Food and Agriculture Organization of the United Nations (FAO), Rome, ISBN:978-92-5-106181-7.

4. Botías C., Martín-Hernández R., Barrios L., Meana A., Higes M. 2013. Nosema spp. infection and its negative effects on honey bees (Apis mellifera iberiensis) at the colony level. Veterinary Research, 44, 25. doi: 10.1186/1297-9716-44-25.

5. Chemurot M., De Smet L., Brunain M., De Rycke R., de Graaf, D.C. 2017. Nosema neumanni n. sp. (Microsporidia, Nosematidae), a new microsporidian parasite of honeybees, Apis mellifera in Uganda. European Journal of Protistology, 61, Part A, 13-19. doi: 10.1016/j.ejop.2017.07.002. 
6. Ellis J.D., Graham J.R., Mortensen A. 2013. Standard methods for wax moth research. Journal of Apicultural Research, 52, 1, 1-17. doi: 10.3896/ IBRA.1.52.1.10.

7. Fenoy S., Rueda C., Higes M., Martín-Hernández R., del Aguila C. 2009. High-level resistance of Nosema ceranae, a parasite of the honeybee, to temperature and desiccation. Applied and Environmental Microbiology, 75, 21, 6886-6889. doi: 10.1128/AEM.01025-09.

8. Fries I. 1988. Infectivity and multiplication of Nosema apis Z. in the ventriculus of the honey bee (Apis mellifera L.). Apidologie, 19, 3, 319-328.

9. Fries I. 1993. Nosema apis - a parasite in the honey bee colony. Bee World 74, 5-19. doi: 10.1080/0005772X.1993.11099149.

10. Fries I., Chauzat M. P., Chen Y. P., Doublet V., Genersch E., Gisder S., Higes M., McMahon D. P., Martín-Hernández R., Natsopoulou M., Paxton R. J., Tanner G., Webster T. C., Williams G. R. 2013. Standard methods for Nosema research, Journal of Apicultural Research, 52, 1, 1-28. doi: 10.3896/ IBRA.1.52.1.14.

11. Higes M., Garcı-Palencia P., Martın-Hernandez R., Meana A. 2007. Experimental infection of Apis mellifera honeybees with Nosema ceranae (Microsporidia). Journal of Invertebrate Pathology, 94, 211-217. doi:10.1016/j.jip.2006.11.001.

12. Higes, M., Martın-Hernandez, R., Garrido-Bailon, E., Gonzalez-Porto, A.V., Garcia-Palencia, P., Meana, A., del Nozal M. J., Mayo R., Bernal J. L. 2009 Honeybee colony collapse due to Nosema ceranae in professional apiaries. Environmental Microbiology Reports, 1, 110-113. doi:10.1111/ j.1758-2229.2009.00014.x.

13. Higes M., Martın-Hernandez R., Meana A. 2010. Nosema ceranae in Europe: anemergent type C nosemosis. Apidologie, 41, 3, 375-392. doi : 10.1051/apido/2010019.

14. MacInnis C.I.,, Keddie B.A., Pernal S.F. 2020. Nosema ceranae (Microspora: Nosematidae): A Sweet Surprise? Investigating the Viability and Infectivity of N. ceranae Spores Maintained in Honey and on Beeswax. Journal of Economic Entomology, 113, 5, 2069-2078. doi: 10.1093/jee/toaa170.

15. McGowan J., De la Mora A., Goodwin P.H., Habash M., Hamiduzzaman M.M., Kelly P.G., Guzman-Novoa E. 2016. Viability and infectivity of fresh and cryopreserved Nosema ceranae spores. Journal of Microbiological Methods, 131, 16-22. doi: 10.1016/j.mimet.2016.09.021.

16. Malone L.A., Gatehouse H.S., Tregidga E.L. 2001. Effects of time, temperature, and honey on Nosema apis (Microsporidia: Nosematidae), a parasite of the honeybee, Apis mellifera (Hymenoptera: Apidae). Journal of Invertebrate Pathology, 77, 4, 258-268. doi: 10.1006/jipa.2001.5028. 
17. Martín-Hernández R., Meana A., García-Palencia P., Marín P., Botías C., Garrido-Bailón E., Barrios L., Higes M. 2009. Effect of temperature on the biotic potential of honeybee microsporidia. Applied and Environmental Microbiology, 75, 8, 2554-2557. doi: 10.1128/AEM.02908-08.

18. Martın-Hernandez R., Bartolome C., Chejanovsky N., Le Conte Y., Dalmon A., Dussaubat C., Garcia-Palencia P., Meana A., Pinto A. M., Soroker V., Higes M. 2018. Nosema ceranae in Apis mellifera: a 12 years post detection perspective, Environmental Microbiology, 20, 4, 1302-1329. doi: $10.1111 / 1462-2920.14103$.

19. Mutinelli F. 2011. The spread of pathogens through trade in honey bees and their products (including queen bees and semen): overview and recent developments, Revue scientifique et technique, 30, 1, 257-271. doi: 10.20506/rst.30.1.2033.

20. Ozgor E., Celebier I., Ulusoy M., Keskin N. 2017. First detection of nosema ceranae and nosema apis in greater wax moth galleria mellonella. Journal of Apicultural Science, 61, 2, 185-192. doi: 10.1515/jas-2017-0015.

21. Pelin A., Selman M., Aris-Brosou S., Farinelli L., Corradi N. 2015. Genome analyses suggest the presence of polyploidy and recent humandriven expansions in eight global populations of the honeybee pathogen Nosema ceranae. Environmental Microbiology, 17, 11, 4443-4458. doi: 10.1111/1462-2920.12883.

22. Ptaszynska A.A., Borsuk G., Mulenko W., Demetraki-Paleolog J. 2014. Differentiation of Nosema apis and Nosema ceranae spores under Scanning Electron Microscopy (SEM). Journal of Apicultural Research, 53, 5, 537-544. doi: 10.3896/IBRA.1.53.5.02.

23. Retschnig G., Williams G. R., Schneeberger A., Neumann P. 2017 Cold Ambient Temperature Promotes Nosema spp. Intensity in Honey Bees (Apis mellifera). Insects, 8, 1, 20. doi:10.3390/insects8010020.

24. Van der Zee R., Gomez-Moracho T., Pisa L., Sagastume S., Garcia-Palencia P., Maside X., Bartolomé C., Martín-Hernández R., Higes M.2014. Virulence and polar tube protein genetic diversity of Nosema ceranae (Microsporidia) field isolates from Northern and Southern Europe in honeybees (Apis mellifera iberiensis).Environmental Microbiology Reports, 6, 4, 401413. doi: 10.1111/1758-2229.12133.

Received: 05.12.2021.

Accepted: 31.12.2021. 